\title{
Pengaruh Pemberian Kacang Hijau (Phaseolus radiatus L.) terhadap Pencegahan Peningkatan Kadar Glukosa Darah pada Tikus (Rattus novergicus) Galur Wistar Bunting
}

\author{
Debby Amalia Briliansari ${ }^{\star}$, Bambang Prijadi**, Fajar Ari Nugroho***
}

\begin{abstract}
ABSTRAK
Selama kehamilan terjadi peningkatan kadar glukosa darah seiring bertambahnya usia kehamilan. Pilihan sumber karbohidrat yang tepat diperlukan agar kadar glukosa darah terkontrol selama kehamilan, sehingga dapat mencegah terjadinya diabetes melitus gestasional. Kacang hijau mengandung serat larut tinggi dan memiliki indeks glikemik rendah. Kandungan tersebut dapat mengurangi penyerapan karbohidrat dalam tubuh, sehingga dapat menurunkan kadar glukosa darah. Tujuan penelitian ini untuk mengetahui pengaruh pemberian kacang hijau terhadap pencegahan peningkatan kadar glukosa darah pada tikus putih Wistar yang bunting. Penelitian ini bersifat true experimental in vivo dengan rancangan post test only with control group design. Sampel yang digunakan adalah tikus Wistar usia 2-3 bulan yang bunting. Tikus dibagi dalam empat kelompok yaitu kelompok normal tidak diberi kacang hijau (P0), perlakuan 1 diberi kacang hijau 0,3 g/hari (P1), perlakuan 2 diberi kacang hijau 0,6 g/hari (P2), dan perlakuan 3 diberi kacang hijau 1,2 g/hari (P3). Diketahui bahwa kacang hijau mampu mencegah peningkatan kadar glukosa darah pada tikus Wistar bunting, meski tidak signifikan $(p=0,494)$. Dosis efektif kacang hijau adalah 0,6 g/ekor/hariyang mampu mengontrol kadar glukosa darah sebesar $88,60 \pm 8,17 \mathrm{mg} / \mathrm{dl}$.
\end{abstract}

Kata kunci: Glukosa darah, Kacang hijau, Kehamilan.

\section{Mung Bean (Phaseolus radiatus L.) Effect on Preventing Increased Blood Glucose in Pregnant Wistar Rat}

\begin{abstract}
During pregnancy, blood glucose will increaseas the age of pregnancy become older. An alternative of carbohydrate are needed to control blood glucose level during pregnancy. So, it can prevent gestasional diabetes mellitus. Mung bean have high soluble fiber and low glycemic index. It can decrease carbohydrate absorption in digestion, so that blood glucose level will decrease. The aim of this study was to find out mung bean effect on preventing increased blood glucose in pregnant rat. The method used was experimental in vivo with post test only with control group design. This study involve 2-3 months old pregnant rat. They were divided into four groups, they were control group (P0), and three treatment groups consist of mung bean 0.3 $\mathrm{g} /$ day (P1), $0.6 \mathrm{~g} /$ day (P2), and $1.2 \mathrm{~g} /$ day (P3) respectively. The result showed that mung bean was able to prevent blood glucose increased level in pregnant rat, although not significant $(p=0.494)$. It was concluded that the dose of mung bean which effective to control blood glucose level $(88.60 \pm 8.17 \mathrm{mg} / \mathrm{dll})$ was $0.6 \mathrm{~g} /$ day .
\end{abstract}

Keywords: Blood glucose,Mung bean,Pregnancy.

* Program Studi S1 Kebidanan, FKUB

** Laboratorium Biokimia-Biomolekuler, FKUB

*** Program Studi Gizi, FKUB 


\section{PENDAHULUAN}

Kehamilan menyebabkan terjadinya banyak perubahan hormonal dan metabolik sehingga kebutuhan energi dan zat gizi lainnya meningkat selama kehamilan. Metabolisme dan kebutuhan energi pada tubuh ibu semakin meningkat seiring pertumbuhan janin. ${ }^{1}$ Salah satu metabolisme ibu yang mengalami perubahan adalah metabolisme glukosa.

Pada trimester kedua dan ketiga, terjadi peningkatan resistensi insulin hingga $80 \%$. Resistensi insulin yang semakin meningkat seiring usia kehamilan yang bertambah, menyebabkan kadar glukosa ibu semakin tinggi. Keadaan tersebut dapat meningkatkan resiko terjadinya diabetes melitus gestasional. Menurut American Diabetes Association (ADA) tahun 2000, diabetes melitus gestasional terjadi $7 \%$ pada kehamilan setiap tahunnya. Prevalensi diabetes gestasional bervariasi yaitu $1-14 \%$. Di Indonesia, prevalensi diabetes melitus gestasional berkisar 1,9-3,6\% pada kehamilan umumnya. ${ }^{2}$ Sementara pada ibu hamil dengan riwayat keluarga diabetes melitus, prevalensi diabetes gestasional sebesar $5,1 \%{ }^{3}$ WHO memperkirakan penderita diabetes melitus di Indonesia meningkat hingga 250\% menjadi sekitar 21,3 juta pada tahun $2030 .^{4}$

Salah satu cara untuk mencegah terjadinya diabetes adalah dengan mengatur asupan karbohidrat. Karbohidrat merupakan sumber energi utama yang dibutuhkan untuk pertumbuhan dan perkembangan janin selama kehamilan. ${ }^{5}$ Maka dari itu, diperlukan pilihan sumber karbohidrat yang tepat bagi ibu hamil agar kadar glukosa darah ibu terkontrol dan kebutuhan energi janin tetap terpenuhi. Banyak sumber karbohidrat yang dapat menjadi pilihan asupan makanan bagi ibu hamil, antara lain hasil olahan dari padipadian atau serealia, umbi-umbian, kacangkacangan, dan gula. Salah satu jenis kacang-kacangan yang baik untuk dikonsumsi oleh ibu hamil adalah kacang hijau. ${ }^{6}$

Kacang hijau merupakan tumbuhan kacang-kacangan yang mudah dijumpai di Indonesia. Kacang hijau telah dikenal baik untuk kesehatan. Kacang hijau memiliki kandungan karbohidrat dan serat yang baik. 7 Kacang hijau mengandung karbohidrat rendah yaitu $19 \mathrm{~g} / 100 \mathrm{~g}$, jauh lebih rendah dibandingkan beras yang mengandung karbohidrat $79,95 \mathrm{~g} / 100 \mathrm{~g}$, dan kentang $35,11 \mathrm{~g} / 100 \mathrm{~g}$. Kandungan serat yang tinggi pada tumbuhan ini sekitar $7,6 \mathrm{~g} / 100 \mathrm{~g}$, lebih tinggi dibandingkan beras yang mengandung serat $1,3 \mathrm{~g} / 100 \mathrm{~g}$, dan kentang $3,2 \mathrm{~g} / 100 \mathrm{~g} .{ }^{8}$

Suatu penelitian di Amerika membuktikan bahwa diet serat yang tinggi mampu memperbaiki pengontrolan gula darah, menurunkan peningkatan insulin yang berlebihan di dalam darah serta menurunkan kadar lemak darah. ${ }^{9}$ Pemberian kacang merah yang juga mengandung serat tinggi, dapat menurunkan kadar glukosa darah pada tikus Wistar jantan model diabetes melitus. ${ }^{10}$

Selain rendah karbohidrat dan tinggi serat, kacang hijau juga memiliki nilai indeks glikemik yang rendah sebesar 28,87 . Nilai indeks glikemik dikategorikan rendah apabila $<55$, kategori sedang 55-70, dan kategori tinggi $>70.11,12$. Pangan dengan indeks glikemik rendah dapat memperbaiki respons glukosa darah dan mengonsumsi makanan yang memiliki nilai indeks glikemik rendah membantu menurunkan kadar glukosa darah secara perlahan sehingga akan membantu mengontrol kadar glukosa darah dalam tubuh. ${ }^{11,13}$

Berdasarkan uraian di atas, kacang hijau berpotensi sebagai pilihan nutrisi bagi ibu hamil. Selain harga yang terjangkau dan mudah dijumpai di Indonesia, kacang hijau mengandung banyak zat gizi yang dibutuhkan oleh ibu hamil. Oleh karena itu, penelitian ini dirancang sebagai tahap awal 
untuk mengetahhui pengaruh pemberian kacang hijau (Phaseolus radiatus L.) terhadap pencegahan peningkatan kadar glukosa darah pada tikus putih strain Wistar (Rattus novergicus) Bunting.

\section{BAHAN DAN METODE}

Penelitian ini bersifat true experimental in vivo dengan rancangan post test only with control group design. Sampel yang digunakan adalah tikus wistar (Rattus novergicus) usia 2-3 bulan yang bunting sebanyak 24 ekor. Tikus dibagi dalam empat kelompok yaitu kelompok normal tidak diberi kacang hijau (P0), perlakuan 1 (P1) diberi kacang hijau 0,3 g/ekor/hari, perlakuan 2 (P2) diberi kacang hijau 0,6 g/ekor/hari, dan perlakuan 3 (P3) diberi kacang hijau 1,2 g/ekor/hari. Kacang hijau disondekan selama 18 hari dengan melarutkan tepung kacang hijau dalam aquades. Kadar glukosa darah diukur sesudah perlakuan dengan glukometer Nesco, dengan mempuasakan tikus selama 12 jam terlebih dahulu.

\section{HASIL}

\section{Kadar Glukosa Darah Tikus Sesudah Pemberian Kacang Hijau}

Pemeriksaan kadar glukosa darah dilakukan sesudah perlakuan. Sebelum perlakuan dan saat perlakuan tidak dilakukan pemeriksaan kadar glukosa darah. Sampel darah diambil dari vena lateralis pada ujung ekor tikus. Rerata kadar glukosa darah dapat dilihat pada Gambar 1.

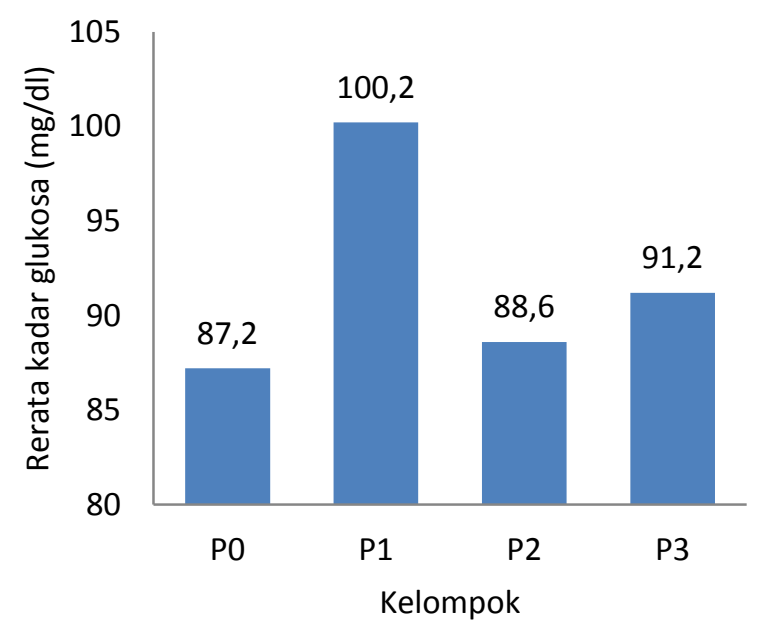

Gambar 1. Rerata kadar glukosa darah sesudah pemberian kacang hijau

Gambar 1 menunjukkan hasil glukosa darah tertinggi tampak pada kelompok P1

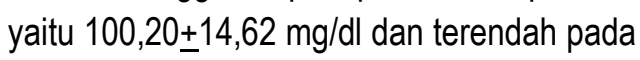
kelompok P0 yaitu $87,20 \pm 21,22 \mathrm{mg} / \mathrm{dl}$. Sementara kelompok P2 memiliki rata-rata kadar glukosa darah mendekati rata-rata kadar glukosa darah pada kelompok P0, yaitu $88,60 \pm 8,17 \mathrm{mg} / \mathrm{dl}$. Tingginya kadar glukosa darah pada kelompok P1 dalam penelitian ini kemungkinan disebabkan oleh beberapa faktor yang dapat mempengaruhi kadar glukosa darah. Beberapa faktor tersebut antara lainfaktor hormonal dan usia kehamilan tikus, nilai indeks glikemik kacang hijau sesudah pengolahan, serta faktor stres tikus akibat kesalahan prosedur.

Hasil uji normalitas data menunjukkan bahwa data terdistribusi normal $p=0,692(p$ $>0,05$ ). Selanjutnya dilakukan uji homogenitas varian data yang menunjukkan bahwa data homogen $p=0,064(p>0,05)$, hal ini menunjukkan bahwa seluruh sampel 
yang digunakan dalam penelitian ini adalah sama dan sejenis.

Karena memenuhi uji normalitas dan uji homogenitas, dilanjutkan dengan uji one-way ANOVA. Hasil uji one-way ANOVA menunjukkan tidak terdapat perbedaan yang signifikan pada semua perlakuan $p=0,494$ $(p>0,05)$, hal ini menunjukkan bahwa tidak terdapat perbedaan yang signifikan pada kadar glukosa darah tikus sesudah pemberian kacang hijau selama 18 hari.

\section{PEMBAHASAN}

\section{Karakteristik Sampel}

Karakteristik sampel yang digunakan adalah tikus putih (Rattus novergicus) galur Wistarbetina yang bunting dengan umur rata-rata 2-3 bulan dan dalam keadaan sehat selama penelitian. Sampel penelitian berjumlah 24 ekor tikus yang dibagi menjadi 4 kelompok perlakuan secara acak agar tikus memiliki peluang yang sama untuk menjadi sampel pada tiap perlakuan.

Pada penelitian ini, usia kehamilan tikus tidak sama dan tidak bisa ditentukan. Perbedaan usia kehamilan ini menyebabkan perbedaan hormonal selama kehamilan pada setiap tikus, sehingga mempengaruhi kadar glukosa darah. Mekanisme hormon kehamilan dalam mempengaruhi kadar glukosa darah adalah dengan memicu terjadinya resistensi insulin. Resistensi insulin menyebabkan peningkatan glukosa darah selama kehamilan. Hormon utama yang berperan penting dalam terjadinya resistensi insulin dalam kehamilan adalah hormon plasenta $(\mathrm{hPL}){ }^{14}$

Pada penelitian ini, faktor hormonal seperti hormon plasenta pada tikus tidak diteliti. Namun, faktor hormonal pada tikus mungkin menjadi salah satu faktor terbesar yang mempengaruhi kadar glukosa darah sesudah perlakuan.

\section{Pemberian Kacang Hijau pada Tikus Bunting}

Kacang hijau dengan dosis $0,3,0,6$, dan 1,2 g/ekor/hari secara berturut-turut diberikan per oral melalui sonde pada kelompok P1, P2, dan P3. Pada penelitian ini, kacang hijau dipilih karena mengandung serat larut yang tinggi. Serat mampu membentuk karbohidrat kompleks sehingga mengurangi daya cerna karbohidrat. Keadaan tersebut dapat menurunkan pelepasan glukosa sehingga kadar glukosa dapat terkontrol. ${ }^{15}$

Hasil penelitian terdahulu menunjukkan bahwa diet serat tinggi yang diberikan pada 80 partisipan selama 2 minggu dapat menurunkan kadar glukosa postprandial, atau kadar glukosa 2 jam sesudah makan. Karbohidrat kompleks dan serat larut mampu menghambat penyerapan glukosa. Kemampuan serat larut dalam mengurangi daya cerna karbohidrat, menyebabkan karbohidrat seperti disakarida maupun polisakarida dalam makanan akan tercerna dan terserap lebih lambat. ${ }^{16}$ Hal ini menjelaskan mekanisme kadar glukosa menjadi lebih rendah pada 2 jam sesudah makan. ${ }^{17}$

Serat mampu menurunkan kadar glukosa postprandial dengan tiga mekanisme, yaitu serat makanan meningkatkan viskositas usus halus dan menghambat difusi glukosa, mengikat glukosa dan mengurangi konsentrasi glukosa dalam usus halus, menghambat aksi a-amilase melalui selaput pati dan enzim serta dapat langsung menghambat enzim. Mekanisme-mekanisme tersebut menurunkan kadar penyerapan glukosa dan konsentrasi glukosa postprandial. ${ }^{18.19}$

Pada penelitian ini, kadar glukosa darah tikus yang diukur adalah kadar glukosa puasa, yaitu tikus dipuasakan selama 12 jam sebelum pengambilan sampel darah. Indikator tersebut berbeda dengan indikator dalam penelitian Yuan (2014), yang 
menggunakan indikator kadar glukosa darah 2 jam sesudah makan. Perbedaan indikator yang diukur mungkin menjadi salah satu penyebab hasil penelitian ini berbeda dengan hasil penelitian tersebut. ${ }^{16}$

Sementara peneliti lain menyebutkan bahwa tidak terdapat perbedaan yang signifikan pada kadar glukosa puasa sesudah pemberian serat larut berupa pektin selama 3 minggu. ${ }^{20}$ Hasil penelitian tersebut memperkuat dugaan bahwa serat larut berpengaruh terhadap kadar glukosa darah puasa berbeda dengan kadar glukosa darah 2 jam setelah makan.

Selain kandungan serat larut yang tinggi, kacang hijau dipilih dalam penelitian ini karena memiliki indeks glikemik yang rendah. Indeks glikemik adalah respon glukosa darah terhadap makanan dibandingkan dengan respon glukosa darah terhadap glukosa murni. ${ }^{21}$ Setiap bahan pangan memiliki indeks glikemikyang akan mempengaruhi kadar glukosa darah dalam tubuh.

Mengonsumsi makanan dengan indeks glikemik rendah dianjurkan untuk penderita diabetes melitus. Makanan dengan indeks glikemik rendah membantu penderita diabetes melitus dalam mengontrol berat badan, meningkatkan sensitivitas tubuh terhadap insulin, menjaga kadar glukosa tetap terkontrol, mengurangi resiko penyakit kardiovaskular dan membantu mengontrol kadar kolesterol. Pada ibu hamil, makanan dengan indeks glikemik rendah bermanfaat untuk mencegah diabetes melitus gestasional, mengontrol kolesterol ibu, dan memberikan rasa kenyang yang bertahan lama sehingga pola makan ibu tetap terjaga. ${ }^{22}$

Indeks glikemik suatu bahan pangan dipengaruhi oleh beberapa faktor, diantaranya kandungan serat pangan dalam bahan pangan. Mekanisme serat pangan dalam mempengaruhi indeks glikemik adalah dengan menurunkan efisiensi penyerapan karbohidrat, sehingga menghambat peningkatan glukosa darah secara cepat dalam tubuh. ${ }^{23}$

Semakin tinggi kandungan serat suatu pangan, maka semakin rendah indeks glikemik makanan tersebut. Semakin rendah indeks glikemik, maka kemampuan karbohidrat untuk menaikkan kadar glukosa darah akan semakin turun, sehingga mengonsumsi bahan pangan dengan indeks glikemik rendah dapat mengontrol kadar glukosa darah. ${ }^{11}$

Selain dipengaruhi oleh kadar serat pangan, faktor lain yang mempengaruhi indeks glikemik adalah proses pengolahan. Proses pengolahan mempengaruhi daya cerna dan daya serap suatu bahan pangan. Semakin tinggi daya cerna dan daya serap suatu makanan maka semakin cepat menaikkan kadar glukosa darah, sehingga semakin tinggi pula nilai indeks glikemik makanan tersebut . ${ }^{24}$

Proses pengolahan yang dapat mempengaruhi indeks glikemik diantaranya adalah pengecilan ukuran (penepungan). Penepungan menyebabkan ukuran partikel suatu makanan menjadi lebih kecil dan memperbesar luas permukan yang dapat diserang oleh enzim, sehingga semakin cepat pencernaan dan penyerapan karbohidrat. Oleh sebab itu, semakin kecil ukuran partikel suatu makanan maka nilai indeks glikemik makanan tersebut akan semakin tinggi. ${ }^{24}$

Dalam penelitian ini, kacang hijau diberikan dalam bentuk pengolahan berupa tepung, hal ini memungkinkan indeks glikemik pada kacang hijau menjadi lebih tinggi dibandingkan sebelum pengolahan, sehingga dapat mempengaruhi hasil akhir penelitian. Namun, pada penelitian ini nilai indeks glikemik kacang hijau sebelum dan sesudah pengolahan tidak diukur.

Dari penjelasan di atas, faktor-faktor yang mungkin mempengaruhi hasil akhir penelitian berkaitan dengan kacang hijau 
antara lainpengaruh serat larut terhadap kadar glukosa darah puasa, yang berbeda dengan kadar glukosa darah 2 jam setelah makan, dan proses pengolahan berupa penepungan, yang mungkin menyebabkan nilai indeks glikemik kacang hijau menjadi lebih tinggi.

\section{Kadar Glukosa Darah Tikus Sesudah Pemberian Kacang Hijau}

Pada penelitian ini, darah sampel diambil dari vena lateralis pada ujung ekor, kemudian kadar glukosa diukur dengan glukometer. Dari hasil analisis data telah diketahui bahwa tidak terdapat perbedaan yang signifikan pada kadar glukosa darah tikus semua kelompok $p=0,494(p>0,05)$. Dari semua kelompok perlakuan, hanya kelompok P2 yang memiliki rerata kadar glukosa darah mendekati kelompok P0, artinya pemberian kacang hijau dosis 2 sebesar 0,6 g/ekor/hari mampu mencegah peningkatan kadar glukosa darah pada tikus bunting, meski tidak signifikan secara statistik.

Selain faktor-faktor yang telah dijelaskan, faktor kemungkinan lain yang mempengaruhi hasil akhir penelitian adalah perlakuan hewan coba atau handling procedure. Berbagai handling procedure pada hewan coba tikus yang meliputi perawatan tikus, pembersihan kandang, penggantian sekam, penyondean, pengambilan sampel darah, injeksi subkutan, penimbangan berat badan, dan dekapitasi, menyebabkan peningkatan denyut jantung dan tekanan darah pada tikus, sehingga menimbulkan stres. ${ }^{25}$

Handling procedure yang dilakukan dalam penelitian ini meliputi perawatan tikus, pembersihan kandang, penggantian sekam, penyondean, dan pengambilan sampel darah. Handling procedure yang tidak dilakukan dalam penelitian ini meliputi injeksi subkutan, penimbangan berat badan, dan dekapitasi. Namun, seberapa besar tingkat stres tikus tidak diukur pada penelitian ini. Dalam penelitian ini, tidak dilakukan pengukuran denyut jantung dan tekanan darah pada tikus, sehingga tidak dapat diketahui seberapa besar tingkat stres tikus akibat handling procedure. Tikus dalam kondisi stres dapat ditunjukkan dengan kadar glukosa darah tikus di akhir penelitian yang cenderung meningkat.

Kondisi tersebut dapat terjadi dikarenakan stres merangsang pengaktifan seluruh sistem saraf simpatis, sehingga salah satu efeknya adalah peningkatan konsentrasi glukosa darah. ${ }^{27} \mathrm{Hal}$ ini menjelaskan bahwa stres yang dialami oleh tikus pada penelitian ini dapat mempengaruhi kadar glukosa darah, sehingga mempengaruhi hasil akhir penelitian.

\section{Keterbatasan Penelitian}

Adanya confounding factor yang tidak bisa dikendalikan oleh peneliti yaitu: faktor hormonal dan usia kehamilan tikus, nilai indeks glikemik kacang hijau, serta faktor stres tikus. Faktor-faktor tersebut dapat mempengaruhi kadar glukosa darah, sehingga mungkin mempengaruhi hasil penelitian.

\section{KESIMPULAN}

Pemberian kacang hijau (Phaseolus radiatus L.) mampu mencegah peningkatan kadar glukosa darah pada tikus putih galur Wistar (Rattus novergicus) bunting, meski tidak signifikan secara statistik.Dosis efektif kacang hijau dalam mencegah peningkatan kadar glukosa darah pada tikus adalah dosis 2 yaitu 0,6 g/ekor/hari, dengan rata-rata kadar glukosa darah sebesar $88,60 \pm 8,17$ $\mathrm{mg} / \mathrm{dl}$.

\section{SARAN}


- Perlu kolaborasi dengan pakar ilmu gizi untuk dilakukan pengukuran nilai indeks glikemik kacang hijau sebelum dan sesudah pengolahan untuk mengetahui perubahan nilai indeks glikemik kacang hijau.

- Perlu kolaborasi dengan pakar ilmu gizi untuk dilakukan penelitian lebih lanjut tentang pemberian kacang hijau dalam bentuk olahan lain, seperti kacang hijau rebus.

\section{DAFTAR PUSTAKA}

1. Rahmaniar A, Nurpudji AT, Burhanuddin B. Faktor-Faktor yang Berhubungan dengan Kekurangan Energi Kronis pada Ibu Hamil di Tampa Padang, Kabupaten Mamuju, Sulawesi Barat.Media Gizi Masyarakat Indonesia. 2013; 2(2): 98103.

2. SoewondonoP dan Laurentius $P$. Prevalence, Characteristics, and Predictors of Pre-Diabetes in Indonesia. J Med.2011.20(4):283-294.

3. Maryunani A. Buku Saku Diabetes Pada Kehamilan. Jakarta: Trans Info Media. 2008.

4. SugondoS. Buku Ajar IImu Penyakit Dalam: Obesitas. Sudoyo AWdkk (Editor). Jakarta: Pusat Penerbitan Departemen IImu Penyakit Dalam Fakultas Kedokteran Universitas Indonesia. Jilid III. Edisi Ke-4. 2006.

5. MaryanahSNNdkk. Asuhan Kebidanan Antenatal. Jakarta: EGC. 2006.

6. JafarN. Diabetes Mellitus. Makassar: Prodi Ilmu Gizi FKM UNHAS. 2004.

7. DiahMD. Kandungan Gizi Kacang Hijau. (Online).2010.

http://diahmd.student.umm.ac.id/2010/0 6/25/kandungan-gizi-kacanghijau/.Diakses 27 Februari 2014.

8. USDA. Basic Report 20044, Rice, white, long-grain, regular, raw, enriched. USDA National Nutrient Database for Standard
Reference Release 27. The National Agricultural Library. (Online). 2014. http://www.nal.usda.gov. Diakses 24 Oktober 2014.

9. Joseph G. Manfaat Serat Bagi Kesehatan Kita. Bogor: Institut Pertanian Bogor.2002.

10. Farman S. Pengaruh Pemberian Ekstrak Kacang Merah (Vigna angularis) terhadap Penurunan Kadar Glukosa Darah Tikus Wistar Jantan yang Diberi Beban Glukosa. Semarang: Media Medika Muda Fakultas Kedokteran Universitas Diponegoro.2012.

11. Powel KF, Holt SH and Miller JC. International Table of Glycemic Index Load Values.Am J Clin Nutr. 2002; 76:556.

12. Eliasson AC. Strach in Food. Woodhead Publishing Limited Cambridge England.2004.

13. Liljeberg HGM, Åerberg AKE, Björk IME. Effect of the Glycemic Index and Content of Indigestible Carbohydrates of Cereal-Based Breakfast Meals on Glucose Tolerance at Lunch in Healthy Subjects. Am J Clin Nutr.1999; 69(4): 647-655.

14. Barbour, Linda A., Carriee McCurdyet al. Cellular Mechanisms for Insulin Resistance in Normal Pregnancy and Gestational Diabetes.Diabetes Care. 2007; 30(2): S112-S119.

15. SantosoA. Serat Pangan (Dietary Fiber) dan Manfaatnya Bagi Kesehatan. Magistra.2011; 75: 35-40.

16. YuanJYF et al. The Effects of Functional Fiber on Postprandial Glycemia, Energy Intake, Satiety, Palatability and Gastrointestinal Wellbeing: A Randomized Crossover Trial.Nutrition Journal.2014; 13(76): 1-9.

17. KabirAUl et al. Anti-Hyperglycemic Activity Of Centella asiaticais Partly Mediated By Carbohydrase Inhibition And Glucose-Fiber Binding.BMC 
Complementary and Alternative Medicine. 2014; 14(31):1-14.

18. Chandalia Met al. Beneficial of High Dietary Fiber Intake in Patient with Type 2 Diabetes and Hypercholesterolemia. $N$ Engl J Med. 2000;342(19):1392.

19. Ou S, K Kin-Chor, Y Li and L Fu. In Vitro Study of Possible Role of Dietary Fiber in Lowering Postprandial Serum Glucose. J Agric Food Chem. 2001; 49: 1026-1029.

20. SavastanoDMet al. Effect of Two Dietary Fibers on Satiety and Glycemic Parameters: a Randomized, DoubleBlind, Placebo-Controlled, Exploratory Study. Nutrition Journal.2014; 13(45): 111.

21. Rimbawan dan Albiner Siagian. Indeks Glikemik Pangan. Bogor: Penebar Swadaya.2004.

22. Itokindo. Apa itu Glikemik Indeks (GI) dan Manfaatnya.Manajemen Modern dan Kesehatan Masyarakat. (Online). 2011.http://www.itokindo.org. Diakses 26 Oktober 2014.

23. AstawanM. Tetap Sehat dengan Produk Makanan Olahan. Solo: Tiga Serangkai.2004.

24. KusnandarF. Apa yang Dimaksud Indeks Glikemik?. (Online). 2010.http://itp.fateta.ipb.ac.id/id/index2.p hp?option=com_content\&do_pdf=1\&id= 140. Diakses 27 Februari 2014.

25. BalcombeJP, Neal DB, Chad S. Laboratory Routines Cause Animal Stres.American Association for Laboratory Animal Science. 2004; 43(6): 42-51.

26. Guyton. Fisiologi Manusia dan Mekanisme Penyakit. Petrus Andrianto (Penerjemah).Edisi ke-3. Jakarta: EGC.2000. 


\title{
Pengaruh Substitusi Sari Umbi Bit (Beta vulgaris L.) terhadap Kadar Kalium, Pigmen Betalain dan Mutu Organoleptik Permen Jeli
}

\author{
Fazanurivana Hanifan*, Amalia Ruhana**, Dwi Yuni Nur Hidayati***
}

\begin{abstract}
ABSTRAK
Salah satu masalah kesehatan yang banyak dijumpai di Indonesia adalah penyakit kardiovaskular seperti hipertensi. Umbi bit merah bermanfaat untuk menurunkan tekanan darah dan sebagai antioksidan. Pengolahan umbi bit merah menjadi permen jeli dapat digunakan sebagai alternatif makanan kudapan untuk mencegah hipertensi. Penelitian ini bertujuan untuk mengetahui pengaruh substitusi sari umbi bit merah terhadap kadar kalium, kadar pigmen betalain serta mengetahui mutu organoleptik yang meliputi tekstur, warna, rasa dan aroma pada permen jeli. Metode yang digunakan dalam penelitian ini adalah dengan rancangan acak lengkap (RAL). Perlakuan yang digunakan adalah sebagai berikut P0 (air $40 \%$ dan gula 60 $\%$ ), P1 (sari umbi bit $70 \%$ dan gula $30 \%$ ), P2 (Sari umbi bit $60 \%$ dan gula $40 \%$ ), P3 (Sari umbi bit $50 \%$ dan gula $50 \%$ ), P4 (sari umbi bit $40 \%$ dan gula $60 \%$ ). Hasil penelitian ini menunjukkan ada pengaruh signifikan antara penambahan sari umbi bit pada permen jeli terhadap kandungan kalium $(p<0,001)$ dan pigmen betalain $(p<0,001)$, dengan kandungan kalium dan pigmen betalain tertinggi pada perlakuan P2 yaitu sebesar $153,79 \mathrm{mg} / 100 \mathrm{~g}$ dan 1,356 mg/100 g. Kelompok P3 merupakan hasil perlakuan terbaik dengan kadar kalium $151,17 \mathrm{mg} / 100 \mathrm{~g}$, kadar pigmen betalain $1,288 \mathrm{mg} / 100 \mathrm{~g}$, serta persentase tingkat kesukaan panelis terhadap aroma (P3) $100 \%$, rasa (P3) $96 \%$, tekstur (P2 dan P3) $92 \%$ dan warna (P2 dan P3) $96 \%$. Kesimpulan dari penelitian ini adalah permen jeli dengan substitusi sari umbi bit dan gula dapat meningkatkan kadar kalium dan pigmen betalain serta mutu organoleptik.
\end{abstract}

Kata kunci: Kalium, Mutu Organoleptik, Permen Jeli, Pigmen Betalain, Umbi Bit Merah.

\section{Substitution Effect of Red Beet (Beta vulgaris L.) Juice to Potassium Concentration, Betalain Peigment,and Organoleptic Quality of Jelly Candy}

\begin{abstract}
One of the health problems that are encountered in Indonesia is cardiovascular diseases, such as hypertension. Red beet contains a lot of benefit including lowering blood pressure and plays as an antioxidant. Processing of red beets into jelly candy can be an alternative food to prevent hypertension. This research aim was to know the influence of the substitution of red beet juice contains of potassium, betalain peigments and the organolepticquality (texture, color, taste, and aromatic) of jelly candy. The methods used was randomized complete desaign. The treatment groups were P0 (water $40 \%$ and sugar $60 \%$ ), P1 (red beets juice $70 \%$ and sugar $30 \%$ ), P2 (red beets juice $60 \%$ and sugar $40 \%$ ), P3 (red beet juice $50 \%$ and sugar $50 \%$ ), and P4 (red beet juice $40 \%$ and sugar $60 \%$ ). Results showed that there was significant influence between the substitution of red beets juice in jelly candy on the potassium content $(p<0.001)$ and betalains pigment $(p<0.01)$. The highest potassium content $(153.79 \mathrm{mg} / 100 \mathrm{~g})$ and betalains pigments $(1.356 \mathrm{mg} / 100 \mathrm{~g})$ were found in P2. Whereas the group P3 was the best treatment with potassium level was $151.17 \mathrm{mg} / 100 \mathrm{~g}$, betalain pigments level was $1.288 \mathrm{mg} / 100 \mathrm{~g}$ and the percentage of panelist liking score were aroma (P3) $100 \%$, taste (P3) $96 \%$, color (P2 and P3) $92 \%$ and texture (P2 and P3) $96 \%$. This research concluded that jelly candies with a substitution of red beets juice and sugar can increase the potassium concentration, betalain pigments and organoleptic quality.
\end{abstract}

Keywords : Betalain pigments, Jelly candy, Organoleptik, Potassium, Red beet.

*Program Studi Ilmu Gizi, FKUB

**Laboratorium Mikrobiologi Fakultas Kedokteran Universitas Brawijaya 


\section{PENDAHULUAN}

Kejadian hipertensi di dunia mencapai $33,1 \%$ dari seluruh kejadian penyakit yang ada. Prevalensi hipertensi pada penduduk umur lebih dari 18 tahun di Indonesia adalah sebesar $31,7 \%$ dan terdapat 10 provinsi yang memiliki prevalensi di atas angka nasional, salah satunya adalah provinsi Jawa Timur yang merupakan urutan tertinggi kedua dengan prevalensi $37,4 \%$ setelah provinsi Kalimantan Selatan dengan prevalensi $39,6 \%{ }^{1}$

Hipertensi adalah arus tekanan darah sistolik $\geq 140 \mathrm{mmHg}$ atau arus tekanan darah diastolik $\geq 90 \mathrm{mmHg}$. Hipertensi sering disebut dengan sillent killer atau pembunuh diam-diam karena penderita hipertensi mengalami kejadian tanpa gejala selama beberapa tahun dan kemudian mengalami stroke atau gagal jantung fatal. ${ }^{2}$

Umbi bit merupakan umbi yang tinggi antioksidan karena mengandung pigmen betalain yang merupakan kombinasi pigmen ungu betacyanin dan pigmen kuning betaxhanthin yang dapat berfungsi sebagai pewarna alami. ${ }^{3}$ Dari penelitian yang ada, umbi bit diketahui dapat menurunkan tekanan darah seseorang dengan meminum $200 \mathrm{ml} /$ hari. Rata-rata tekanan darah sistolik menurun $11,48 \mathrm{mmHg}$ sedangkan tekanan diastolik $5,75 \mathrm{mmHg}{ }^{4}$

Kalium merupakan ion intraseluler dan dihubungkan dengan mekanisme pertukaran natrium. Peningkatan asupan kalium dalam diet telah dihubungkan dengan penurunan tekanan darah karena kalium memicu natriuresis yaitu dapat memicu kehilangan natrium lewat urin. ${ }^{5}$ Sementara antioksidan yang terdapat dalam pigmen betalain adalah senyawa yang dapat melindungi sistem biologis dalam tubuh. Adanya stres oksidatif yaitu ketidakseimbangan antara radikal bebas dan antioksidan dalam tubuh dapat mengganggu vasorelaksasi dari endotel yang dapat mengakibatkan adanya hipertensi. ${ }^{6}$

Permen jeli adalah salah satu bentuk makanan olahan dari pendidihan campuran gula dan air atau sari buah dengan bahan pembentuk gel yang berpenampilan jernih transparan serta mempunyai tekstur dengan kekenyalan tertentu. Pemanfaatan umbi bit digunakan sebagai permen jeli karena permen jeli merupakan makanan ringan yang praktis dan disukai oleh berbagai kalangan masyarakat. Selain itu, umbi bit mengandung kalium dan pigmen betalain yang bersifat sebagai antioksidan sehingga permen jeli bit yang dihasilkan dapat menjadi permen jeli tinggi kalium dan antioksidan yang dapat digunakan sebagai pengobatan alternatif untuk pasien hipertensi.

Pigmen yang terdapat dalam umbi bit juga dapat memberikan warna ungu kemerahan yang akan membuat permen menjadi menarik tanpa penambahan pewarna sintetis. 7,8 Pengujian terhadap mutu organoleptik dilakukan dengan tujuan untuk mengetahui tingkat kesukaan konsumen terhadap permen jeli bit. ${ }^{9}$

Tujuan dari penelitian ini adalah untuk mengetahui pengaruh substitusi sari umbi bit terhadap kadar kalium, pigmen Betalain serta mutu organoleptik pada permen jeli bit.

\section{BAHAN DAN METODE}

Penelitian ini menggunakan metode rancangan acak lengkap (RAL) dengan 25 sampel dari masing-masing perlakuan dengan 5 kali pengulangan. Perlakuan yang digunakan adalah:

$\mathrm{P0}=40 \%$ air : $60 \%$ gula pasir

$\mathrm{P} 1=70 \%$ sari umbi bit : $30 \%$ gula pasir

$\mathrm{P} 2=60 \%$ sari umbi bit : $40 \%$ gula pasir

$\mathrm{P} 3=50 \%$ sari umbi bit : $50 \%$ gula pasir

Variabel independen adalah sari umbi bit dan gula. Sedangkan variabel dependen adalah kadar kalium, pigmen betalain dan mutu organoleptik. Pembuatan resep 
permen jeli bit, bahan dikelompokkan menjadi dua bagian yaitu bahan $A$ terdiri dari gelatin dan sari bit sedangkan bahan $B$ terdiri dari gula pasir, sari bit, asam sitrat, glukosa, dan vanili. Setelah umbi diubah dalam bentuk sari, langkah selanjutnya adalah dengan mencampur (bahan A) hingga larut kemudian disisihkan terlebih dahulu. Sari bit dengan agar-agar direbus kemudian bahan B dimasukkan secarabertahap hingga mendidih. Adonan bahan $A$ dan bahan $B$ dicampur hingga suhu mencapai $90{ }^{\circ} \mathrm{C}$.Larutan dituang kedalam cetakan dan didinginkan pada suhu ruang selama 24 jam. Uji kalium dan uji pigmen betalain dengan menggunakan uji spektrofotometer. Analisis statistik menggunakan software SPSS 16 dengan uji oneway ANOVA untuk kadar kalium dan pigmen betalain serta uji Kruskall Wallisuntuk mutu organoleptik.

\section{HASIL}

\section{Kandungan Kalium Permen Jeli Bit}

Kadar kalium dari sampel bervariasi dari $68,131 \mathrm{mg}$ sampai $153,79 \mathrm{mg}$. P2 memiliki kandungan kalium tertinggi dibandingkan dengan perlakuan permen jeli bit lainnya. Sementara PO memiliki kandungan kalium terendah. Hasil uji statistik one way ANOVA pada tingkat kepercayaan $95 \%(p<0,05)$ menunjukkan bahwa semakin banyak proporsi sari umbi bit memberikan perbedaan yang signifikan $(p<0,001)$ terhadap kandungan kalium.

\section{Kandungan Pigmen Betalain Permen Jeli Bit}

Kandungan pigmen betalain berkisar antara $0 \mathrm{mg}$ hingga $1,351 \mathrm{mg}$. P2 memiliki kandungan pigmen betalain tertinggi sedangkan P0 memiliki kandungan pigmen betalain terendah. Hasil uji statistik Kruskal Wallis pada tingkat kepercayaan $95 \%$ ( $p$ < $0,05)$ menunjukkan bahwa semakin banyak proporsi sari umbi bit memberikan perbedaan yang signifikan $(p<0,001)$ terhadap kandungan pigmen betalain.

\section{Mutu Organoleptik Permen Jeli Bit Aroma}

Persentase tertinggi penerimaan panelis terhadap aroma permen jeli ditunjukkan pada sampel perlakuan P3 yaitu sebesar $100 \%$. Sementara persentase penerimaan panelis yang terendah ditunjukkan pada sampel perlakuan P1 sebesar $84 \%$. Hasil uji statistik dengan tingkat kepercayaan $95 \%$ ( $p$ $<0,05$ ) menunjukkan bahwa penambahan sari umbi bitdalam pembuatan permen jeli tidak memberikan perbedaan yang signifikan $(p=0,063)$.

\section{Rasa}

Persentase tertinggi penerimaan panelis terhadap rasa permen jeli ditunjukkan pada sampel perlakuan P3 yaitu sebesar $96 \%$. Sementara persentase penerimaan panelis yang terendah ditunjukkan pada sampel perlakuan P1 yaitu sebesar $48 \%$.

Hasil uji statistik dengan menggunakan Kruskal Wallis pada tingkat kepercayaan 95 $\% \quad(p<0,05)$ menunjukkan bahwa penambahan sari umbi bit dalam pembuatan permen jeli memberikan perbedaan yang signifikan $(p<0,001)$.

\section{Tekstur}

Persentase tertinggi penerimaan panelis terhadap tekstur permen jeli ditunjukkan pada sampel perlakuan P0 yaitu sebesar $100 \%$. Sementara persentase penerimaan panelis yang terendah ditunjukkan pada sampel perlakuan P1 dan P4 yaitu sebesar $60 \%$. Hasil uji statistik Kruskal Wallis pada tingkat kepercayaan $95 \% \quad(p<0,05)$ menunjukkan bahwa penambahan sari umbi bit dalam pembuatan permen jeli memberikan perbedaan yang signifikan $(p=$ 0,010). 
Warna

Persentase tertinggi penerimaan panelis terhadap warna permen jeli ditunjukkan pada sampel perlakuan P0, P2, dan P3 yaitu sebesar $96 \%$. Sementara persentase penerimaan panelis yang terendah ditunjukkan pada sampel perlakuan P4 yaitu sebesar $80 \%$. Hasil uji statistik dengan menggunakan Kruskal Wallispada tingkat kepercayaan $95 \%(p<0,05)$ menunjukkan bahwa penambahan sari umbi bitdalam pembuatan permen jeli memberikan perbedaan yang signifikan $(p=0,010)$.

\section{Penentuan Taraf Perlakuan Terbaik}

Kandungan gizi diberi bobot tertinggi yaitu 0,25 karena memiliki penilaian yang lebih terhadap produk. Bobot rasa 0,2; tekstur 0,15 ; warna 0,1 ; aroma 0,05 . Nilai hasil perlakuan terbaik didapatkan dari perhitungan nilai efektifitas masing-masing perlakuan. Sehingga diperoleh hasil yang ditunjukkan pada Gambar 2 dengan perlakuan terbaik dari permen jeli bit berdasarkan kandungan kalium, pigmen betalain, dan mutu organoleptik adalah P3.

Tabel 1. Perbandingan kadar kalium dan pigmen betalain

\begin{tabular}{lccccc}
\hline \multicolumn{1}{c}{ Mutu gizi } & P0 & P1 & P2 & P3 & P4 \\
\hline Kailum & 68,131 & 139,07 & 153,79 & 151,17 & 146,61 \\
Pigmen Betalain & 0,000 & 1,044 & 1,351 & 1,306 & 1,238 \\
\hline
\end{tabular}

Aroma

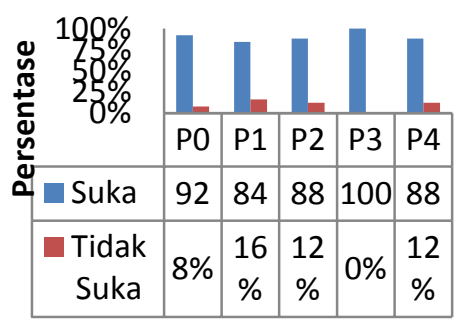

Tekstur

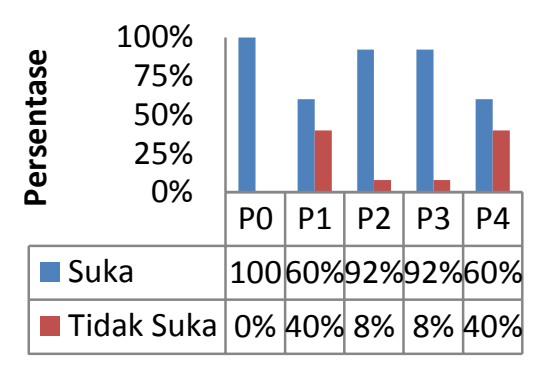

\section{Rasa}

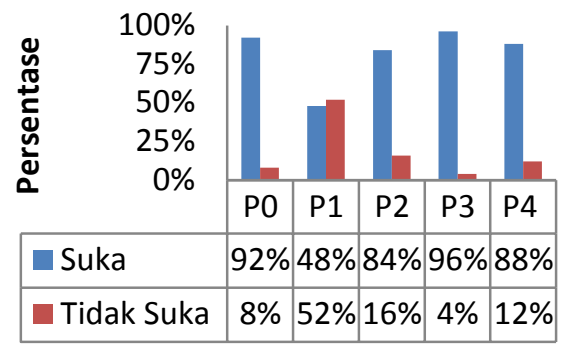

Warna

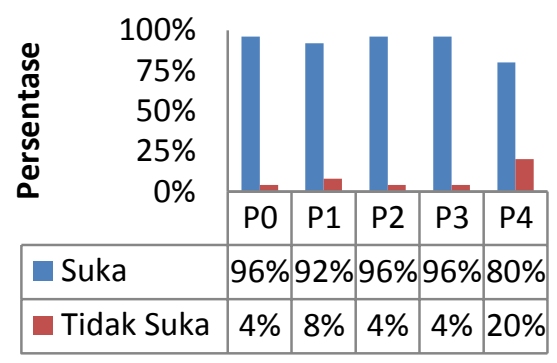

Gambar 1. Penilaian mutu organoleptik permen jeli bit 


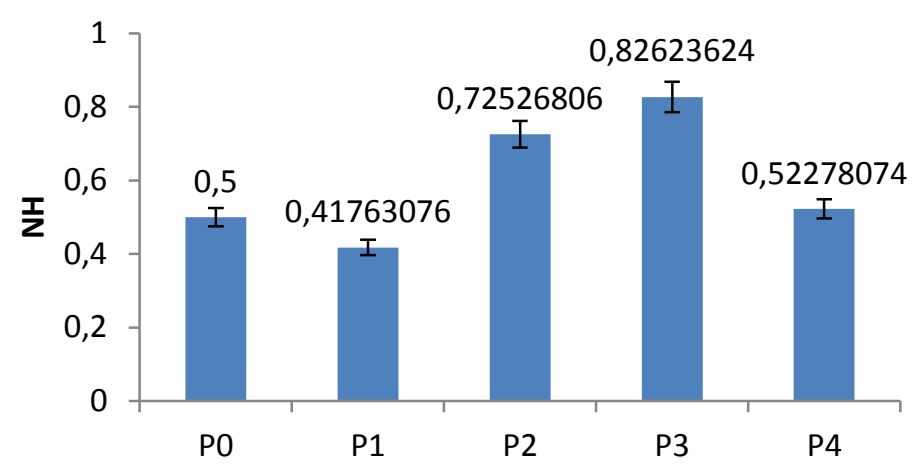

Gambar 2. Penilaian perlakuan terbaik permen jeli bit (Tambahkan figure legend)

\section{PEMBAHASAN}

\section{Kandungan Kalium pada Permen Jeli Bit}

Rata-rata kandungan kalium permen jeli pada masing-masing taraf perlakuan berkisar antara 68,131-153,79 mg. Kandungan kalium dalam sari umbi bit hampir menyerupai kadar kalium dalam pisang sebesar $435 \mathrm{mg} / 100 \mathrm{~g}$ Sedangkan kalium dalam sari umbi bit adalah 434,656 mg/100 g. ${ }^{10}$ Terjadinya naik turun kadar kalium pada keseluruhan perlakuan dapat dipengaruhi oleh faktor-faktor selama pengolahan permen jeli. Faktor-faktor yang perlu diperhatikan antara lain seperti jumlah dan jenis bahan yang digunakan, kecepatan mengaduk, waktu perebusan, suhu, serta metode penyimpanan.

Lama pemasakan yang berbeda-beda di setiap perlakuan disebabkan karena konsentrasi gula dan jumlah air yang ditambahkan dalam pembuatan permen jeli. Penggunaan air dalam jumlah yang tepat mempengaruhi efisiensi proses pemasakan dan penggunaan energi. Jadi diharapkan proses pemasakan bisa dilakukan dengan suhu rendah dengan waktu yang lebih singkat. Semakin sedikit air yang digunakan maka proses pemasakan semakin cepat meskipun dengan menggunakan suhu rendah. ${ }^{11}$
Suhu berhubungan dengan daya larut gula dalam pembuatan permen. Kekentalan dari sukrosa berbanding lurus dengan konsentrasi dan berbanding terbalik dengan suhu. Kekentalan sangat berpengaruh terhadap tekstur produk yang dihasilkan. ${ }^{12}$

Pada sampel P1 memiliki kandungan air yang paling banyak yang berpengaruh terhadap pemasakan permen jeli semakin lama dalam mencapai suhu yang sesuai. Proses pemanasan dapat menyebabkan penurunan kadar kalium sehingga kadar kalium pada sampel memiliki nilai terendah. Hal ini didukung oleh penelitian, bahwa proses pemanasan dengan perebusan menyebabkan penurunan kadar kalium lebih banyak apabila dibandingkan dengan pengukusan. ${ }^{13}$

\section{Kandungan Pigmen Betalain Permen Jeli Bit}

Rata-rata kandungan pigmen betalain permen jeli pada masing-masing taraf perlakuan berkisar antara 0-1,351 mg. Sari umbi bit yang ditambahkan pada permen jeli memiliki kandungan pigmen betalain sebesar $55,447 \mathrm{mg}$, sedangkan gula tidak memiliki kandungan pigmen betalain. Semakin banyak penambahan proporsi sari umbi bit maka kandungan pigmen betalain pada permen jeli semakin meningkat. 
Betalain sangat rentan terhadap panas dengan suhu optimal pemanasan $\pm 65{ }^{\circ} \mathrm{C} .1^{14}$ Kandungan betalain umbi bit merah sebesar 127,62 mg/ 100 g..$^{15}$ Kandungan betalain dalam sari umbi bit merah lebih kecil jika dibandingkan dengan umbi bit merah. Hal ini karena dalam proses pembuatan sari umbi bit merah dengan juicer masih banyak betalain yang tertinggal pada ampas. Hal ini ditandai dengan adanya warna merah dari ampas tersebut.

Paparan cahaya juga dapat mempengaruhi penurunan kadar betalain pada permen jeli bit. Peningkatan intensitas cahaya berdampak pada degradasi warna sirup bit merah yang semakin besar. ${ }^{15} \mathrm{Hal}$ ini serupa dengan pendapat Azeredo dkk (2007), bahwa degradasi betasianin akan meningkat dengan meningkatnya paparan cahaya ${ }^{16}$. Lama penyinaran menyebabkan stabilitas betasianin semakin menurun dan meningkatkan kerusakan betasianin.adanya absorbsi cahaya menyebabkan bagian ikatan rangkap dalam betalain akan terputus, sehingga intensitas warna menurun.

Penggunaan sari umbi bit dalam jumlah banyak pada sosis daging sapi, akan meningkatkan aktivitas antioksidannya. ${ }^{17} \mathrm{Hal}$ ini disebabkan karena pigmen betalain dalam umbi bit merupakan senyawa antioksidan. Kandungan betasianin sebanyak $5,7 \mathrm{mg} / 100 \mathrm{~g}$ memiliki antioksidan sebanyak $13 \% .{ }^{18}$

\section{Mutu Organoleptik \\ Aroma}

Persentase penerimaan panelis terhadap aroma permen jeli bit berkisar antara $84-100 \%$ dengan persentase tertinggi pada P3 dan terendah pada P1. Semakin banyak sari umbi bit yang ditambahkan, aroma cenderung berbau tanah. Petriana dkk (2012), berpendapat mengenai penambahan sari umbi bit dengan konsentrasi 2,5-12,5\% dalam pembuatan sirup menunjukkan bahwa semakin tinggi konsentrasi sari umbi bit merah yang ditambahkan, semakin tidak disukai oleh panelis. ${ }^{15} \mathrm{Hal}$ ini disebabkan karena adanya aroma yang berbau tanah. ${ }^{19}$

\section{Rasa}

Persentase penerimaan panelis terhadap rasa permen jeli bit berkisar antara 48-96 \% dengan persentase tertinggi pada P3 dan terendah pada P1. Pada perlakuan P3 memiliki penerimaan tertinggi disebabkan oleh rasa manis selain ditimbulkan dari gula juga berasal dari umbi bit sehingga pada sampel tersebut rasa disukai oleh panelis karena komposisi perbandingan yang sesuai antara gula dan sari umbi bit.

Semakin banyak sari umbi bit yang ditambahkan, penerimaan terhadap rasa semakin rendah. Hal ini membuktikan bahwa bau tanah mempengaruhi rasa yang terdapat pada permen jeli bit. Berdasarkan penelitian Wahyuni (2011) menyatakan bahwa semakin banyak penambahan kulit buah naga super merah memperoleh persentase kesukaan terendah. ${ }^{20} \mathrm{Hal}$ ini disebabkan karena masih ada rasa langu yang terdapat pada kulit buah naga super merah.

\section{Tekstur}

Persentase penerimaan terhadap tekstur permen jeli bit tertinggi pada P2 dan P3 yaitu $92 \%$, sedangkan persentase terendah pada perlakuan P1 yaitu $60 \%$. Hal ini menunjukkan bahwa panelis tidak menyukai produk yang lembek. Tekstur yang lembut atau lembek karena tingginya kandungan air dalam produk.

Berdasarkan penelitian (Hasniarti, 2012) menyatakan bahwa semakin rendah sari buah yang ditambahkan pada permen jeli maka persentase penerimaan terhadap tekstur permen jeli semakin tinggi. ${ }^{8} \mathrm{Hal}$ ini disebabkan karena konsentrasi gula yang tinggi berpengaruh pada efisiensi pemasakan yang lebih cepat. 
Warna

Presentase tertinggi permen jeli bit adalah P2 dan P3 yatu sebesar $96 \%$. Sementara presentase terendah P4 yaitu 80 $\%$. Hal ini disebabkan karena gula yang dibentuk atau saat dipanaskan membentuk karamelisasi sehingga menghasilkan warna yang lebih gelap daripada penambahan sari umbi bit yang banyak. Hal ini didukung oleh Koswara (2009) bahwa pembentukan karamel dapat membantu mempertajam warna produk. ${ }^{21}$

Berdasarkan penelitian Wahyuni (2011) menunjukkan bahwa semakin sedikit penambahan kulit buah naga super merah pada permen jeli maka memiliki persentase kesukaan tertinggi. ${ }^{20} \mathrm{Hal}$ ini disebabkan karena warna permen jeli dengan penambahan kulit buah naga merah dengan persentase rendah memiliki warna merah bening.

\section{Penentuan Taraf Perlakuan Terbaik}

Sampel yang memiliki nilai perlakuan terbaik adalah sampel P3 hal ini disebabkan karena adanya komposisi yang seimbang antara pemberian sari umbi bit dan gula sehingga secara keseluruhan memiliki nilai tertinggi oleh panelis diikuti dengan kandugan kalium dan pigmen betalain yang tinggi. Sementaranilai perlakuan terendah adalah sampel P1. Hal ini dikarenakan penilaian panelis terhadap produk yang rendah juga memiliki kandungan kalium dan betalain yang paling rendah.

\section{Implikasi terhadap Bidang Gizi}

Menurut segi kandungan gizi kalium, kandungan kalium pada sampel permen jeli paling banyak memiliki kandungan 153,79 $\mathrm{mg} / 100 \mathrm{~g}$ setara dengan 3 buah permen jeli. Untuk memenuhi target sumber kalium (10 $\%$ AKG) jumlah permen jeli bit yang harus di konsumsi adalah sebanyak 305,6 gram permen jeli bit. Apabila 1 buah permen jeli memiliki berat sekitar 38,4 gram, maka untuk memenuhi target tersebut, seseorang harus mengkonsumsi 8 buah permen jeli atau 307,2 gram.

\section{Keterbatasan Penelitian}

Kurangnya kontrol waktu dan pengadukan pada saat perebusan sari umbi bit sehingga akan mempengaruhi pemerataan suhu dalam adonan permen jeli bit. Selain itu, juga pengaruh kurangnya kontrol penyimpanan pada saat umbi bit sebelum diproses dan saat pendinginan permen jeli. Sehingga umbi bit mengalami oksidasi sehingga kandungan betalain dalam permen jeli berkurang. Warna yang dihasilkan pada permen jeli tidak terlalu bening karena tidak dilakukan penyaringan terlebih dahulu sebelum adonan permen dimasukkan ke dalam cetakan.

\section{KESIMPULAN}

Terdapat pengaruh positif antara penambahan sari umbi bit dengan kandungan kalium dan pigmen betalain serta mutu organoleptik pada permen jeli bit.

\section{SARAN}

Berdasarkan hasil yang didapat dari penelitian ini, maka disarankan pada penelitian selanjutnya untuk mengukur kadar gula, mutu fisik serta pengaruh penyimpanan terhadap kandungan kalium dan betalain dari permen jeli bit. Selain itu, dapat diberikan bentuk olahan lain dari bit yang dapat mempertahankan kandungan kalium dan betalain agar tetap tinggi.

\section{DAFTAR PUSTAKA}

1. Riset Kesehatan Dasar. Jakarta: Badan Penelitian dan Pengembangan Kesehatan, Departemen Kesehatan, Republik Indonesia. 2007. 
2. Aisyiyah FN. Faktor Resiko Hipertensi pada Empat Kabupaten/Kota dengan Prevalensi Hipertensi Tertinggi di Jawa dan Sumatera. Skripsi. Bogor: Departemen Gizi Masyarakat Institut Pertanian Bogor.2009.

3. Yenawaty L. Pengaruh Suhu dan Batas Waktu Penggorengan terhadap Aktivitas Antioksidan "Snack Mie Pelangi" yang Disuplementasi dengan Sawi Hijau (Brassica juncea), Bit (Beta vulgaris), Kunyit (Curcuma domestica val.). Skripsi. Semarang: FakultasTeknologi Pertanian Universitas Katolik Soegijapranata. 2011.

4. Halim SS. Pengaruh Jus Beet (Beta vulgaris L.) terhadap Tekanan Darah. Skripsi. Bandung: Fakultas Kedokteran Universitas Kristen Marantha. 2011.

5. Kerry $J$ and $D$ Ledward. Meat Processing. New York: CRC press. 2001.

6. Barasi M. Nutrition at a Glance. Hermin (Penerjemah). Jakarta: Penerbit Erlangga. 2009. HIm 52.

7. Maslachah dkk. Hambatan Produksi Reactive Oxygen Species Radikal Superoksida ( $\left(\mathrm{O}^{2-}\right)$ oleh Antioksidan Vitamin E (a- tocopherol) padaTikus Putih (Rattus norvegicus) yang Menerima Stressor Renjatan Listrik. Media Kedokteran Hewan. 2008; 24(1).

8. Hasniarti. Studi Pembuatan Permen Buah Dengen (Dillenia serrata Thumb.). Skripsi. Makassar: Jurusan Teknologi Pertanian Universitas Hasanuddin. 2012.

9. Mastuti. Identifikasi Pigmen Betasianin Pada Beberapa Jenis Inflorescence Celosia. Jurnal Biologi Universitas Gajah Mada. 2010.

10. Triyastuti. Pengaruh Konsumsi Pisang Ambon (Musa paradisiaca S) terhadap Tekanan Darah Lansia Penderita Hipertensi Sedang di Panti Sosial Tresna Werdhasabai Nanaluihsi cincin. Skripsi. Padang: Pogram Studi IImu Keprawatan Fakultas Kedokteran Universitas Andalas. 2012.
11. Safitri AA. Studi Pembuatan Fruit Leather Mangga-Rosella. Makassar:Fakultas Pertanian Universitas Hasanudin. 2012.

12. Purba AS. Pengaruh Variasi Konsentrasi Sukrosa terhadap Kualitas Permen Jelly Daun Pepaya (Carica papaya L.). Skripsi. Yogyakarta: Fakultas Teknobiologi Program Studi Biologi.Universitas Atma Jaya. 2011

13. Pambudi ND. Pengaruh Metode Pengolahan terhadap Kelarutan Mineral Keong Mas dari Perairan Situ Gede Bogor. Skripsi. Bogor: Program Studi Teknologi Hasil Perairan. Fakultas Perairan dan IImu Kelautan Institut Pertanian Bogor. 2011.

14. Willianto J. Stabilitas Antioksidan dari Ekstrak Bit Merah (Beta vulgaris) terhadap $\mathrm{pH}$ dan Suhu. Skripsi. Tangerang: Fakultas Teknologi Industri Program Studi Teknologi Pangan Universitas Pelita Harapan. 2011.

15. Petriana G, Lydia NL, Yohanes M. Pengaruh Intensitas Cahaya terhadap Degradasi Warna Sirup yang Diwarnai Umbi Bit Merah (Beta vulgaris L. Var. rubra L.).Salatiga: Program Studi Kimia, Fakultas Sains dan Matematika. Universitas Kristen Satya Wacana. 2012.

16. Azeredo HMC, AN Santos, ACR Souza, kcb Mendes, MIR Andrade. Betacyanin Stability during Processing and Storage of Microencapculated Red Beet root Extract. American Journal of Food Technology. 2000; 2(4):307-312.

17. Winanti ER, Andriani EN. Pengaruh Penambahan Bit (Beta vulgaris) sebagai Pewarna Alami terhadap Karakteristik Fisikokimia dan Sensori Sosis Daging. Jurusan Teknologi Hasil Pertanian Fakultas Pertanian Universitas Sebelas Maret. 2013.

18. Saneto B. Karakterisasi Kulit Buah Naga Merah (H polyrhizus). Jurnal Teknosains Pangan. 2013; 2(4). 
19. Tomezak D Wand Zielinska. Effect of Fermentation Conditions on Red Beet Leaven Quality. Polish Journal of Food and Nutrition Science. 2006; 15(4):436444.

20. Wahyuni R. Pemanfaatan Kulit Buah Naga Super Merah (Hylicereus costaricensis) sebagai Sumber Antioksidan dan Pewarna Alami pada Pembuatan Jelly. Jurnal Teknologi Pangan. 2011; 2(1):68-85.

21. Koswara S. Teknologi Pembuatan Permen.(Online). 2009. http://eBookPangan.com. 


\title{
Pengaruh lon Asing terhadap Kinerja Elektroda Selektif Ion Metanil Yellow Berbasis Aliquat 336-Kitosan sebagai Carrier Membran serta Aplikasinya pada Sampel Tahu
}

\author{
Bheta Sari D*, Atikah**, Hermin Sulistyartił*
}

\begin{abstract}
ABSTRAK
Elektroda selektif ion (ESI) metanil yellow tipe kawat terlapis telah dibuat menggunakan bahan aktif aliquat 336-kitosan, bahan pendukung campuran polivinilklorida (PVC), dan pemlastis dioktiloftalat (DOP) dengan perbandingan aliquat 336:kitosan:PVC:DOP $=0,5 \%: 5 \%: 34,5 \%: 60 \%$ b/b dilarutkan dalam pelarut tetrahidrofuran (THF) (1:3 b/v). Namun, ESI ini belum diuji selektifitasnya. Maka, pada penelitian ini ingin diketahui pengaruh ion asing terhadap kinerja ESI metanil yellow tipe kawat terlapis bermembran aliquat 336-kitosan serta aplikasinya pada sampel tahu. Pengaruh ion asing ditentukan dengan menentukan koefisien selektivitas $\left(\mathrm{K}_{\mathrm{i}, \mathrm{j}}\right)$ membran dengan metode larutan tercampur. Larutan yang diukur mengandung ion utama metanil yellow dengan rentang konsentrasi $10^{-5}-10^{-2} \mathrm{M}$ dan ion asing benzoat $\left(\mathrm{C}_{7} \mathrm{H}_{5} \mathrm{O}_{2}^{-}\right)$, klorida $(\mathrm{Cl})$, dan asetat $\left(\mathrm{CH}_{3} \mathrm{COO}-\right.$ dengan konsentrasi tetap $10^{-3} \mathrm{M}$. Hasil penelitian menunjukkan keberadaan ion asing $\mathrm{C}_{7} \mathrm{H}_{5} \mathrm{O}_{2}-\mathrm{Cl}, \mathrm{CH}_{3} \mathrm{COO}$ - tidak mempengaruhi kinerja ESI yang ditunjukkan oleh nilai $\mathrm{K}_{\mathrm{i}, \mathrm{j}}$ kurang dari 1, dengan urutan selektivitas $\mathrm{C}_{7} \mathrm{H}_{5} \mathrm{O}_{2}>\mathrm{CH}_{3} \mathrm{COO}>\mathrm{Cl}$. Aplikasi pada penentuan kadar metanil yellow secara potensiometri menggunakan ESI metanil yellow tipe kawat terlapis berbasis aliquat 336-kitosan hasilnya dibandingkan dengan metode standar spektrofotometri menggunakan uji-t dengan tingkat kepercayaan $90 \%$ menunjukkan hasil tidak berbeda secara bermakna, sehingga ESI ini dapat digunakan sebagai metoda alternatif untuk pengukuran kadar metanil yellow dalam tahu.
\end{abstract}

Kata kunci: Aliquat 336, Elektroda selektif ion metanil yellow, lon asing, Kitosan,Validasi.

\section{The Influence of Interfering lons to The Performance of Coated Wire Methanyl Yellow lon Selective Electrode (MY-ISE) Based on Chitosan Membrane and Its Application in Tofu Sample}

\begin{abstract}
Coated wire methanyl yellow ion selective electrodes (MY-ISE) was prepared using active material aliquat 336-chitosan, supporting material of a mixture of polyvinylchloride (PVC) and dioctylphtalate (DOP) with ratio of aliquat 336:chitosan:PVC:DOP $=0.5 \%: 5 \%: 34.5 \%: 60 \%$ dissolved in THF (1:3 b/v). However, the selectivity of MY-ISE has not been studied. Therefore, this research was conducted to learn the influence of interfering ions to the performance of MY-ISE and its application to the determination of methanyl yellow in tofu. The influence of interfering ions was done by determining the selective coefficients $\left(\mathrm{K}_{\mathrm{i}, \mathrm{j}}\right)$ membrane with a mixed solution method, containing the primary ion metanil yellow with concentration range $10^{-5}-10^{-2} \mathrm{M}$ and interfering ions of benzoate $\left(\mathrm{C}_{7} \mathrm{H}_{5} \mathrm{O}_{2}{ }^{-}\right)$, chloride $(\mathrm{Cl})$, and acetate $\left(\mathrm{CH}_{3} \mathrm{COO}-\right)$ with fixed concentration of $10^{-3}$ $M$. The results indicated that methanyl yellow ISE performance was not affected by the choosen interfering ions shown by $\mathrm{K}_{\mathrm{i}, j}$ value of less than 1 , with sequence selectivity of $\mathrm{C}_{7} \mathrm{H}_{5} \mathrm{O}_{2}>\mathrm{CH}_{3} \mathrm{COO}>\mathrm{Cl}$. The results obtained from the application of MY-ISE on the determination of methanyl yellow ion in tofu were compared to the standard method spectrophotometry using statistical t-student test with level of confidence $90 \%$, and showed no significant difference with those resulted from standart method spectrophotometry. So, MY-ISE can be used as an alternative method for the measurement of methanyl yellow in tofu.
\end{abstract}

Keywords: Aliquat 336,Chitosan, Interfering ions, Methanil yellow ion selective electrodes, Validation.

* Program Studi Farmasi, FKUB

* Jurusan Kimia, Fakultas MIPA UB 


\section{PENDAHULUAN}

Metanil yellow adalah pewarna sintesis golongan senyawa azo (warna tar batubara), yang digunakan secara luas untuk mewarnai bahan makanan yang berbeda di banyak negara berkembang meskipun dilarang penggunaannya menurut peraturan Menteri Kesehatan Nomor 1168/Menkes/PER/1999. Metanil yellow berbahaya bagi kesehatan dan menyebabkan kerusakan irreversibel. ${ }^{1}$

Metode analitis metanil yellow secara kuantitatif untuk metanil yellow dalam bahan makanan adalah metoda spektrofotometri sinar tampak. Untuk analisis rutin, sederhana, cepat dan biaya yang efektif metode spektrofotometri terlihat diperlukan. Meskipun metode spektrofotometri memiliki akurasi yang tinggi, metode ini memerlukan pereaksi, instrumentasi yang mahal dan tenaga ahli untuk mengoperasikannya. ${ }^{2}$ Oleh karena itu, perlu diciptakan alat analisis yang murah, cepat, tidak perlu tenaga ahli untuk mengoperasikannya dan memenuhi akurasi dan presisi yang tinggi. Pada penelitian ini digunakan metode sensor potensiometri menggunakan elektroda selektif ion (ESI) metanil yellow bermembran aliquat 336kitosan sebagai sensor ionnya untuk mendeteksi metanil yellow.

Pada penelitian sebelumnya ESI metanil yellow telah dibuat menggunakan aliquat $336 \quad 0,5 \%$ :kitosan $5 \%$ :PVC 34,5 $\%$ :DOP $60 \%$. Harga faktor Nernst yang dihasilkan 59,68 mV/dekade konsentrasi, rentang konsentrasi10-5-10 $-2 \mathrm{M}$, waktu perendaman selama 25 menit dengan limit deteksi $0,929.10^{-5} \mathrm{M}$ (3,487 ppm), waktu respon 50 detik dan usia pakai membran selama 7 hari. Sebelumnya juga, telah diuji $\mathrm{pH}$ dan suhu dan didapatkan kondisi optimum pada pH 6-7 dan suhu $25-30{ }^{\circ} \mathrm{C}$. Namun, ESI metanil yellow ini belum diuji terhadap keberadaan ion asing.

Ion asing adalah ion selain ion utama yang telah ditentukan dan terdapat dalam larutan sampel sehingga dapat mempengaruhi pengukuran potensial sel. ${ }^{3}$ Ion asing yang diteliti pengaruhnya dalam penelitian ini antara lain ion asetat $\left(\mathrm{CH}_{3} \mathrm{COO}\right.$ ), ion klorida $\left(\mathrm{Cl}^{-}\right)$dan ion benzoat $\left(\mathrm{C}_{7} \mathrm{H}_{5} \mathrm{O}_{2}{ }^{-}\right)$. Ion-ion tersebut merupakan bahan tambahan yang biasa terdapat dalam makanan seperti tahu yang dapat mengganggu pengukuran ion metanil yellow. Ion asetat $\left(\mathrm{CH}_{3} \mathrm{COO}\right)$ dan ion benzoat $\left(\mathrm{C}_{7} \mathrm{H}_{5} \mathrm{O}_{2}{ }^{-}\right)$yang diteliti merupakan bahan pengawet pada makanan, sedangkan ion klorida $(\mathrm{Cl})$ merupakan bahan perasa pada makanan. Pemiihan konsentrasi ion-ion tersebut digunakan konsentrasi ion tetap sebesar $10^{-3} \mathrm{M}$.

Tahu merupakan suatu produk yang terbuat dari hasil penggumpalan protein kedelai. Tahu dikenal masyarakat sebagai makanan sehari-hari yang umumnya sangat digemari serta mempunyai daya cerna yang tinggi. Banyak penjual yang menambahkan bahan tambahan lain di dalam tahu tersebut, baik yang dilarang maupun yang tidak dilarang. Pewarna metanil yellow merupakan bahan tambahan makanan pada tahu yang dilarang atau tidak boleh ada dalam makanan (0 ppm) menurut peraturan Menteri Kesehatan Nomor 1168/Menkes/PER/1999.

Validasi merupakan konfirmasi melalui pengujian dan pengadaan bukti yang objektif bahwa persyaratan tertentu untuk tujuan khusus dipenuhi. Hasil uji yang absah apabila hasil validasinya diperoleh akurasi (ketepatan) dan presisi (kecermatan) yang baik. Akurasi dinyatakan dengan nilai recovery yang dihitung dari kadar terukur dibagi dengan kadar diketahui dikalikan 100 $\%$, jika nilainya berada pada rentang $90-110$ $\%$ maka metode ini dikatakan baik. Presisi metode analisis dihitung berdasarkan coefficient of variation (CV) yang dihitung dari simpangan baku dibagi nilai rata-rata dikalikan $100 \%$, jika nilainya kurang dari $2 \%$ maka metode ini presisinya baik. Metode uji memegang peranan yang sangat penting dalam memperoleh hasil uji dengan akurasi 
dan presisi tinggi. ${ }^{5}$ Oleh karena itu, tujuan penelitian ini adalah melakukan validasi metode ESI metanil yellow untuk pengujian kadar metanil yellow dalam tahu. Lalu dilakukan uji t (keberartian) dilakukan untuk mengetahui apakah kedua metode tidak memiliki perbedaan yang nyata. Hipotesis nol $\left(\mathrm{H}_{0}\right)$ menyatakan bahwa kedua metode memberikan hasil yang sama atau tidak berbeda nyata.

\section{BAHAN DAN METODE}

\section{Prosedur Pembuatan ESI Metanil Yellow Tipe Kawat Terlapis Berbasis Aliquat 336- Kitosan}

Dari penelitian sebelumnya, didapatkan kondisi optimum yang terdiri dari aliquat 336 0,5 \%:kitosan $5 \%$ :PVC $60 \%$ :DOP 34,5\%. Proses awal yang dilakukan adalah mengekstraksikan aliquat $336 \mathrm{Cl}$ dengan larutan baku metanil yellow sampai didapat aliquat 336 metanil yellow lalu dicampur dengan kitosan, pemlastis, kemudian ditambah pelarut THF $3 \mathrm{ml}$ dengan perbandingan berat komposisi membran:volume THF = 1:3. Setelah itu, ditambahkan PVC sedikit demi sedikit. Selanjutnya, diaduk dengan pengaduk magnetik selama 3 jam sampai diperoleh larutan yang homogen dan tidak terdapat gelembung udara. Pelapisan membran dilakukan dengan mencelupkan ujung kawat platina ke dalam larutan membran sampai larutan membran menempel dan melapisi seluruh permukaan kawat platina. Proses pencelupan elektroda tersebut dilakukan beberapa kali sehingga diperoleh membran yang tipis dan merata. Elektroda yang telah terlapisi membran dikeringkan pada suhu ruang $\left(25^{\circ} \mathrm{C}\right)$ dan dipanaskan dalam oven suhu $50{ }^{\circ} \mathrm{C}$ selama 12 jam agar ketahanan membran meningkat. Setelah dioven, elektroda didinginkan pada suhu ruang.

\section{Pengaruh lon Asing terhadap Kinerja ESI Metanil Yellow Tipe Kawat Terlapis Berbasis Aliquat 336-Kitosan}

Penentuan koefisien selektivitas menggunakan metode larutan tercampur yang dilakukan dengan mengukur potensial larutan yang mengandung ion utama metanil yellow pada rentang konsentrasi linier yang telah ditentukan sebelumnya yaitu pada larutan metanil yellow $10^{-5}-10^{-2} \mathrm{M}$. Selanjutnya dilakukan pula pengukuran potensial larutan metanil yellow $10^{-5}-10^{-2} \mathrm{M}$ dengan penambahan larutan natrium asetat $\left(\mathrm{NaCH}_{3} \mathrm{COOH}\right)$, garam $(\mathrm{NaCl})$, natrium benzoat $\left(\mathrm{C}_{7} \mathrm{H}_{5} \mathrm{O}_{2} \mathrm{Na}\right)$ yang masing-masing mengandung ion pengganggu $\left(\mathrm{NaCH}_{3} \mathrm{COO}\right.$ $10^{-3} \mathrm{M}, \mathrm{Cl}^{-} 10^{-3} \mathrm{M}$ dan $\left.\mathrm{C}_{7} \mathrm{H}_{5} \mathrm{O}_{2}-10^{-3} \mathrm{M}\right)$ dan ditambah akuades sampai volume total 50 $\mathrm{ml}$. Kemudian dilakukan pengukuran sebanyak 3 kali pengulangan. Potensial yang diperoleh dari hasil pengukuran larutan yang hanya mengandung ion utama saja maupun dengan penambahan ion asing disubstitusikan dalam suatu persamaan dan dibuat kurva hubungan antara -log [metanil yellow] dengan $\mathrm{K}_{\mathrm{l}, \mathrm{j}}$, jika $\mathrm{K}_{\mathrm{l}, \mathrm{j}}>1$ maka $\mathrm{ESI}$ metanil yellow lebih merespon secara selektif ion asing daripada ion metanil yellow sendiri, yang berarti ion asing tersebut mengganggu kinerja ESI metanil yellow.

\section{Aplikasi ESI Metanil Yellow Tipe Kawat Terlapis Berbasis Aliquat 336-Kitosan}

Sampel dicuci atau dibersinkan dari pengotornya. Lalu ditimbang 1 gram sampel dan dilarutkan dalam $10 \mathrm{ml}$ aquades dan dikocok dengan vortex selama 30 menit. Kemudian, larutan sampel disaring. Diambil $0,5 \mathrm{ml}$ filtrat dalam tabung dan tambahkan dengan aquades sampai $3 \mathrm{ml}$. Lalu ditambahkan $50 \mu \mathrm{L} \quad \mathrm{HCl} 1 \mathrm{~N}$ sampai terbentuk warna merah muda. ${ }^{5}$ Hasilnya dibandingkan dengan metode spektrofotometri sinar tampak. Data perhitungan diuji t untuk mengetahui apakah kedua metoda berbeda secara bermakna atau tidak. 
HASIL

\section{Pengaruh lon Asing terhadap ESI Metanil Yellow Berbasis Aliquat 336-Kitosan}

Berdasarkan penelitian yang telah dilakukan sebelumnya telah diukur ion metanil yellow tanpa ion asing yang menunjukkan faktor Nernst 59,7 mV/dekade yang hampir mendekati faktor Nernst teoritis yaitu 59,2 mV/dekade. Sementara pada pengukuran ion metanil yellow dengan ion asing benzoat, klorida dan asetat juga menunjukkan Nernstian (Tabel 1).

Tabel 1. Hasil faktor Nernst ion metanil yellow tanpa atau dengan ion asing

\begin{tabular}{|c|c|}
\hline Ton & Faktor Nernst (mV)dekad \\
\hline Ton MY tanpa ion asing & 59,7 \\
\hline Ton MY dengan ion asing Cl & 59,2 \\
\hline Ton MY dengan ion asing $\mathrm{C}_{7} \mathrm{H}_{5} \mathrm{O}_{2}^{-}$ & 59,2 \\
\hline Ton Mr dengan ion asing $\mathrm{CH}_{3} \mathrm{COO}$ & 59,1 \\
\hline
\end{tabular}

\section{Penentuan Panjang Gelombang Maksimum Dengan Spektrofometri Sinar Tampak}

Penelitian ini dilakukan dengan menggunakan konsentrasi metanil yellow $10^{-4} \mathrm{M}$. Panjang gelombang maksimum dalam penentuan metanil yellow secara spektrofotometri pada pembentukan ion metanil yellow (kuning-hijau) memiliki absorbansi maksimum pada kisaran panjang gelombang pada sinartampak yaitu $400,0 \mathrm{~nm}$ dengan nilai absorbansi 0,272 sesuai dengan warna komplementernya (violet).

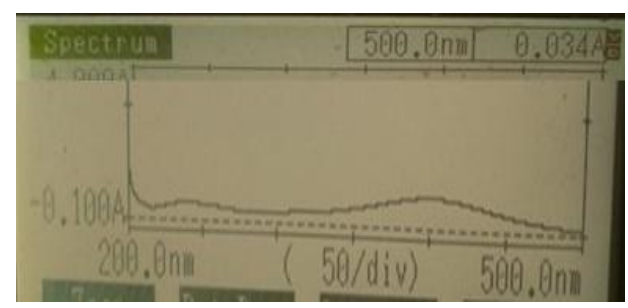

Gambar 1. Profil spektrum dari konsentrasi $10^{-4} \mathrm{M}$

\section{Pembuatan Kurva Baku dan Uji Linieritas}

Uji linieritas dilakukan untuk melihat adanya hubungan linier antara konsentrasi analit dengan respon (serapan) yang ditandai dari nilai koefisien korelasinya $\left(R^{2}\right)$ pada analisis regresi linier $y=a+b x$. Kurva linier dapat dilihat pada Gambar 2, dengan persaman garis regresiy $=0,007 x+0,052$. Dapat dibuktikan dengan nilai koefisen korelasi $=0.999$ hampir mendekati 1 yang berarti menunjukkan adanya korelasi positif antara konsentrasi dengan absorbansi. Nilai intersept (a) yang kecil menunjukkan kesalahan metode kecil. Linieritas berada pada $10^{-6}-10^{-4} \mathrm{M}$.

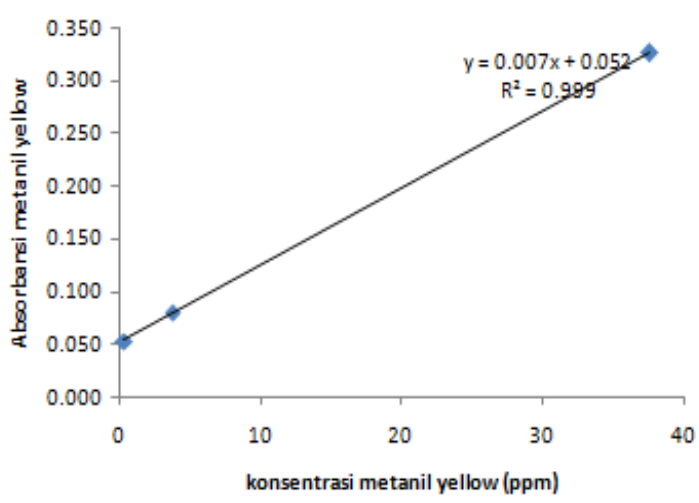

Gambar 2. Kurva baku konsentrasi metanil yellow dengan metode spektrofotometri

\section{Pembuatan Kurva Baku ESI dan Uji Linieritas}

Sebelumnya telah diuji linieritas metode ESI metanil yellow berbasis aliquat 336kitosan yaitu pada $10^{-5}-10^{-2} \mathrm{M}$. Lalu diplot pada kurva baku (Gambar 3).Berdasarkan hasil perhitungan diperoleh persamaan $\mathrm{y}=$ $58,75 x+271,5$ 


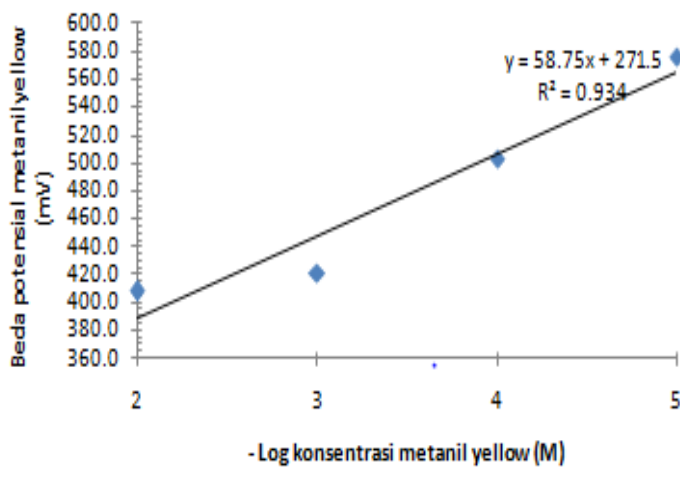

Gambar 3. Kurva baku metode ESI metanil yellow berbasis aliquat 336-kitosan

\section{PEMBAHASAN}

\section{Pengaruh lon Asing terhadap Kinerja ESI Metanil Yellow Berbasis Aliquat 336- Kitosan}

Harga koefisien selektivitas untuk semua konsentrasi ion metanil yellow dari $10^{-5}-10^{-2} \mathrm{M}$ menghasilkan harga Ki,j kurang dari 1. Hal ini menunjukkan bahwa konsentrasi ion $\mathrm{C}_{7} \mathrm{H}_{5} \mathrm{O}_{2}$, $\mathrm{Cl}^{-} \mathrm{CH}_{3} \mathrm{COO}-10^{-3} \mathrm{M}$ tidak mengganggu selektivitas ESI metanil yellow berbasis aliquat 336-kitosan. Hasilnya dapat dilihat pada Tabel 2.

Tabel 2. Koefisien selektivitas $\left(K_{\mathrm{i}, \mathrm{j}}\right)$ ESI metanil yellow berbasis aliquat 336-kitosan terhadap lon $\mathrm{C}_{7} \mathrm{H}_{5} \mathrm{O}_{2}^{-}$, $\mathrm{Cl}^{-}$dan $\mathrm{CH}_{3} \mathrm{COO}$

\begin{tabular}{c|c|c|c}
\hline \multirow{2}{*}[MY]{$(M)$} & \multicolumn{3}{|c}{ Koefisien selektivitas (Ki,i) } \\
\cline { 2 - 4 } & benzoat & Klorida & Asetat \\
\hline $1 \times 10^{-5}$ & $-9,998$ & $-9,999$ & $-9,998$ \\
\hline $1 \times 10^{-4}$ & $-0,999$ & $-0,099$ & $-0,099$ \\
\hline $1 \times 10^{-3}$ & $-0,999$ & $-0,999$ & $-0,999$ \\
\hline $1 \times 10^{-2}$ & $-9,998$ & $-9,990$ & $-9,998$ \\
\hline
\end{tabular}

Berdasarkan nilai $\mathrm{K}_{\mathrm{i}, \mathrm{j}}$ pada Tabel 2 maka urutan selektivitas dari ESI metanil yellow berbasis aliquat 336-kitosan dari ion yang paling direspon sampai yang kurang direspon adalah $\mathrm{C}_{7} \mathrm{H}_{5} \mathrm{O}_{2}>\quad \mathrm{CH}_{3} \mathrm{COO}>\mathrm{Cl}$. Harga koefisien ESI metanil yellow berbasis aliquat 336-kitosan dipengaruhi oleh konsentrasi ion metanil yellow. Hal tersebut dikarenakan perubahan konsentrasi ion metanil yellow dapat mengubah perubahan permitivitas atau konstanta dielektrik $(\varepsilon)$. Sehingga harga Ki,j juga mengalami perubahan sesuai dengan konsentrasi metanil yellow. Pada umumnya harga koefisien selektivitas suatu ion dalam larutan tetap, akan tetapi beberapa diantaranya dapat berubah-ubah akibat pengaruh konsentrasi ion di dalam larutan dan kekuatan interaksi membran ESI terhadap ion utama dan ion pengganggu. Konsentrasi ion pengganggu berpengaruh pada harga koefisien selektivitas. Semakin besar konsentrasi ion pengganggu. Semakin besar harga koefisien selektivitas, semakin besar gangguan ion pengganggu terhadap kinerja ESI.

Selektivitas ESI tergantung pada jarijari ion, entalpi hidrasi dan energi bebas solvasi. Jari-jari ion berbanding lurus dengan hidrofobisitas suatu ion. ESI akan lebih selektif terhadap ion yang lebih hidrofobik. Sehingga dengan jari-jari ion yang semakin besar maka hidrofobisitasnya juga semakin tinggi. Hal ini menunjukkan bahwa, jari-jari ion utama metanil yellow lebih besar dibandingkan dengan ion asing sehingga menyebabkan ion metanil yellow lebih cepat mencapai fasa antar muka membran dan mempermudah difusi ion-ion dalam lapisan rangkap listrik untuk mengontrol potensial Donnan antara membran dan larutan analit, sehingga ion asing akan ditolak keluar oleh membran. Ion metanil yellow lebih berdifusi dengan membran jika dibandingkan dengan ion asing $\mathrm{CH}_{3} \mathrm{COO}-\mathrm{C}_{7} \mathrm{H}_{5} \mathrm{O}_{2}{ }^{-}$dan $\mathrm{Cl}$. Urutan besar jari-jari ion dari yang terbesar hingga terkecil yaitu $\mathrm{C}_{7} \mathrm{H}_{5} \mathrm{O}_{2}>\mathrm{CH}_{3} \mathrm{COO}->\mathrm{Cl}$.

Selektivitas ESI juga dipengaruhi entalpi hidrasi $\left(\Delta \mathrm{H}^{\circ}\right)$ dan energi bebas standar $\left(\Delta \mathrm{G}^{\circ}\right)$ dari ion-ion yang disensornya. Entalpi hidrasi $\left(\Delta \mathrm{H}^{\circ}\right)$ berbanding lurus dengan energi solvasi dan harga Ki,j, yaitu semakin kecil entalpi hidrasi maka mobilitas ion untuk mencapai fasa antar muka 
membran semakin besar dan semakin cepat melewati lapis rangkap listrik sehingga akan mengontrol potensial Donnan. $\Delta H^{\circ}$ berbanding terbalik dengan jari-jari ion dan berbanding lurus dengan kuadrat kerapatan muatan, sehingga semakin besar jari-jari suatu ion maka $\Delta \mathrm{H}^{\circ}$ ion semakin kecil sedangkan jika kerapatan muatan suatu ion semakin besar maka akan mempunyai $\Delta H^{\circ}$ yang semakin besar pula. Sementara energi solvasi adalah kemampuan suatu ion untuk mengikat molekul air. Semakin kecil harga energi solvasi maka ion tersebut sedikit mengikat air dan lebih mengikat pada ion metanil yellow. ${ }^{1}$

Ketika ESI metanil yellow dicelupkan ke dalam larutan analit, terjadi difusi ion-ion dalam lapisan rangkap listrik sebagai potensial Donnan pada fasa antar muka membran-larutan. Ion-ion akan berdifusi melewati bidang helmhoz luar (OHP) dan mengalami pelepasan kulit hidrasinya. Ion akan semakin sulit terhidrasi jika jari-jari hidrasi kecil dan entalpi semakin positif, oleh karena itu laju difusinya semakin tinggi. Ionion yang telah melepas kulit hidrasinya setelah melewati bidang OHP akan berdifusi menuju ke membran melewati bidang helmhoz dalam (IHP). Skema lapis rangkap listrik yaitu pada Gambar 4.

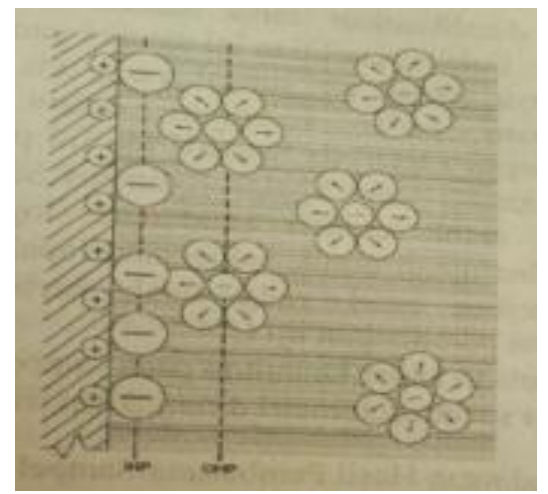

Gambar 4. Skema lapis rangkap listrik pada fasa antar muka ESI metanil yellow
Dalam membran terdapat gugus $\mathrm{HR}$ dan berkedudukan tetap di dalam membran sebagai gugus penukar ion. Pada gugus ini terjadi pertukaran ion metanil yellow dari membran dengan ion metanil yellow dari larutan pada fasa antar muka. Ion $\mathrm{CH}_{3} \mathrm{COO}^{-}$, ion $\mathrm{C}_{7} \mathrm{H}_{5} \mathrm{O}_{2}$, dan ion $\mathrm{Cl}^{-}$adalah ion kontra bagi membran. Ion hidrofobik dan berjari-jari paling besar akan lebih cepat mencapai antar muka membran-larutan dan melewati lapis rangkap listrik sehingga akan mengontrol potensial Donnan. Pada kesetimbangan Donnan, jumlah anion dan kation yang berdifusi ke dalam membran dan larutan adalah sama. Selama penukar ion tetap berada pada permukaan membran, gugus penukar kation akan bermuatan negatif, maka anion lain yang berada bersama-sama dalam larutan sampel akan ditolak keluar membran sehingga tidak berperan sebagai menimbulkan potensial Donnan. Selain itu, proses ini juga ditentukan oleh kemampuan ion dalam melampaui energi solvasi agar dapat menembus bidang helmhoz. Ion yang memiliki koefisien difusi besar akan berdifusi lebih cepat melewati lapis rangkap listrik dan mengontrol potensial Donnan dibandingkan dengan ion yang memiliki koefisien difusi lebih kecil. ${ }^{1}$

\section{Aplikasi ESI Metanil Yellow Berbasis Aliquat 336-Kitosan pada Sampel Tahu}

Berdasarkan hasil pengukuran konsentrasi metanil yellow dalam dua sampel tahu (A dan B) dengan metode potensiometri dan metode spektrofotometri dapat dilihat pada Tabel 3, dapat dilihat bahwa presisi kedua metode sangat baik, yaitu mendekati 100\%. Namun, akurasi kedua metode agak rendah, yaitu mendekati $90 \%$ dan metode standar mempunyai akurasi lebih tinggi dibandingkan dengan metode potensiometri. 
Tabel 3. Perbandingan hasil pembacaan sampel tahudengan metode potensiometri dan metode spektrofotometri

\begin{tabular}{|c|c|c|c|c|c|c|c|}
\hline \multirow[t]{2}{*}{ Sampel } & \multicolumn{3}{|c|}{ Metode potensiometri } & \multicolumn{4}{|c|}{ Metode Spektrofototomerin Vis } \\
\hline & [M] & [-Log konsentrasi] & $\begin{array}{l}\text { Aluras } \\
(\%)\end{array}$ & $\begin{array}{c}\text { Presisis } \\
|\%|\end{array}$ & {$[\mathrm{M}]$} & $\begin{array}{l}\text { Akuras: } \\
(1 \%)\end{array}$ & $\begin{array}{l}\text { Presis } \\
\mid(\%)\end{array}$ \\
\hline A & 0.0001 & 4 & 85.89 & 99.74 & 0.0001 & 90.69 & 9981 \\
\hline \multirow[t]{2}{*}{ B } & 0,00001 & 5 & 89.55 & 99.96 & 0.00001 & 9176 & 99.20 \\
\hline & & RATA2 & 87,72 & 99,85 & RATA2 & 91,23 & 99.51 \\
\hline
\end{tabular}

Perbandingan penentuan kadar metanil yellow dalam sampel tahu A dan B dengan spektrofotometer sinar tampak dan ESI metanil yellow berbasis aliquat 336-kitosan ditunjukkan pada Tabel 3. Berdasarkan hasil uji t Uji-t dengan tingkat kepercayaan $90 \%$, diperoleh nilai thitung untuk sampel tahu $A$ dan B sebesar 0,253 dan 1,542 yang menunjukkan lebih kecil dibandingkan dengan nilai $t_{\text {tabel }}$ sebesar 2,132. Hal ini menunjukkan bahwa metode potensiometri memberikan hasil yang tidak berbeda secara bermakna dengan metode spektrofotometri. Hal tersebut membuktikan bahwa metode potensiometri dengan menggunakan ESI metanil yellow berbasis aliquat 336-kitosan dapat digunakan sebagai metode alternatif selain metode standar spektrofotometer sinar tampak dalam menentukan kadar metanil yellow dalam tahu.

\section{KESIMPULAN}

Berdasarkan hasil penelitian yang telah dilakukan dapat disimpulkan bahwa:

Keberadaan ion asing $\left(\mathrm{C}_{7} \mathrm{H}_{5} \mathrm{O}_{2}^{-}, \quad \mathrm{Cl}\right.$ $\left.\mathrm{CH}_{3} \mathrm{COO}\right) 10^{-3} \mathrm{M}$ tidak mengganggu kinerja ESI metanil yellow tipe kawat terlapis pada rentang $10^{-5}-10^{-2} \mathrm{M}$ karena nilai $K_{i, j}$ yang dihasilkan kurang dari 1. Urutan respon ESI metanil yellow dari ion yang lebih direspon sampai yang kurang direspon adalah $\mathrm{C}_{7} \mathrm{H}_{5} \mathrm{O}_{2}>\mathrm{CH}_{3} \mathrm{COO}>\mathrm{Cl}$. Metode ESI metanil yellow dapat digunakan sebagai metode alternatif penentuan kadar metanil yellow dalam sampel tahu

\section{DAFTAR PUSTAKA}

1. Pratim P, Kaushik S, Panchali $T$, and Goutam P. Development of a Visible Spectrophotometric Method for the Quantitative Determination of Metanil Yellow in Different Food Sample. International Journal of Pharma and Bio Sciences. 2013; 4(2):685-692.

2. D'Angelo et al. Rapid, Sensitive, Micro Scale Anion Membranes. Biionic Potensials with $\mathrm{NO}_{3}{ }^{-}-\mathrm{Cl}^{-}, \mathrm{NO}_{3}{ }^{-} \mathrm{Br}^{-}, \mathrm{Br}$ -Cl- Couples.J Phys Chem.2001; 75:554561.

3. Wijanarko A, Atikah, Fardiyah $Q$. Pengaruh lon Asing terhadap Kinerja Elektroda Selektif Ion (ESI) Cd (II) Tipe Kawat Terlapis Berbasis D2EHPA Serta Aplikasinya pada Penentuan Kadar Kadmium Dalam Air Sungai. Kimia Student Journal. 2013. 2(2):546-552. 
4. Koswara S. Teknologi Pengolahan Kedelai Menjadikan Makanan Bermutu. Jakarta: Pustaka Sinar Harapan. 1995.

5. Mulja M dan Hanwar D. Prinsip-Prinsip Cara Berlaboratorium yang Baik (Good Laboratory Practice). Majalah Farmasi Airlangga.2003; 3(2). 